\title{
MENE MENE TEQEL UPARSIN: DANIEL 5:25 IN CUNEIFORM
}

\section{David Instone Brewer}

The writing on the wall interpreted by Daniel continues to present problems, ${ }^{1}$ despite much work done in the past. One particular problem is why the Babylonians could not read these Aramaic words when Aramaic was an official court language. This paper will propose that the inscription was a number written in cuneiform, which was translated into Aramaic and then interpreted. This may provide indirect links between the composition of the narrative and visionary halves of the book (chs. 1-6 and 7-12).

The exact form of the text is difficult to establish. Theodotion (which became the official Greek text for Daniel) agrees with Josephus and the Vulgate in transliterating the text as if it read 'Mene Teqel Peres', and the older LXX appears to read it as 'Mene Peres Teqel'.

Various theories have been put forward to explain why a second Mene should be added and why the plural Parsin should occur. Lacocque ${ }^{2}$ suggests that the three terms were originally 'Mene Teqel Parsin' which applied to Nebuchadnezzar, Belshazzar and the (plural) Medo-Persians, but that a later redactor added an extra Mene to make them apply to the four Empires of Daniel. Hans Bauer ${ }^{3}$ suggested that the original was 'Mene Teqel Peres Peres' and that the final pair became the plural Parsin. However, both these ideas compound the problem by proposing original text forms which are different again.

\footnotetext{
${ }^{1} \mathrm{~A}$ recent literature review, though not concerned particularly with this problem, is found in C. Steyl, 'Mene Mene Teqel ufarsin: 'n Samevatting van die studies oor hierdie probleemteks,' Nederduits Gereformeerde Teologiese Tydskrif 18 (1977) 199-205. Abstracted in OTA (1978) 56 no. 232. An up-to-date bibliography can be found in Danna Nolan Fewell, $A$ Story of Stories in Daniel 1-6 (Sheffield, Almond Press 1988) 189.

${ }^{2}$ A. Lacocque, The Book of Dantel (tr. D. Pellauer, London, SPCK 1976) 103.

${ }^{3} \mathrm{H}$. Bauer, 'Menetekel', Vierter deutscher Münzforschertag zu Hallels, (1925) 27-30.
} 
By the principle that the most difficult text is the best, the $M T$ is probably nearest to the original. The double Mene in the text is difficult because this duplication is not referred to in the interpretation and the plural Parsin is difficult because it is referred to as a singular in the interpretation. The reading 'Mene Tegel Peres' is the easiest reading because it is consistent with the interpretation in Daniel 5:26-28, so it is most likely to be secondary.

A possible explanation for the plural Parsin has been proposed seemingly independently by A. de Guglielmo ${ }^{4}$ and F. Zimmermann. ${ }^{5}$ They suggest that a redactor changed it to a plural to emphasise the double interpretation in 5:28 as both 'divided' and 'Persians'.

A break-through in the understanding of this text was made by Clermont-Ganneau ${ }^{6}$ who first suggested that these three words represented weights: Mina (60 shekels), Shekel and Peresh (a 'half'). The variant spelling of Teqel for Shekel involves a change of sibilant to dental pronunciation, which is common in Daniel's Aramaic, and this spelling has been found on one papyrus. ${ }^{7}$ The term Peresh is used for a half Mina in rabbinic literature (e.g. bTaan 21b) and has been found on a Babylonian half Mina weight. ${ }^{8}$

This insight introduced a new difficulty. Babylonian weights and numbers normally occur in the order of highest to lowest, so the order should be 'Mina, Mina, Peresh, Shekel'. This prompted Kraeling 9 to put forward a totally new interpretation not proffered by Daniel, which also explained the double Mina. He suggested that these weights represented the rulers Evil-Merodach and Neriglissar (both a Mina), the

\footnotetext{
${ }^{4}$ A. de Guglielmo, 'Daniel 5.25 - An Example of a Double Literal Sense' $C B Q 11$ (1949) 202-206.

5F. Zimmermann, 'The Writing on the Wall: Dan. 5.25f', JQR 55 (1965) 201-207.

${ }^{6} \mathrm{C}$. Clermont-Ganneau, in Journal Asiatique, Juillet-Aout, (1886) 36ff reprinted in Recueil d'Archeologie Orientale I (1888) 136-159.

${ }^{7}$ C. Boutflower, 'Dadda-'Idri or The Aramaic of the Book of Daniel' (London, SPCK undated) 17f. J.A. Montgomery, A Critical and Exegetical Commentary on the Book of Daniel, ICC (Edinburgh, T. \& T. Clark 1927) 263. With regard to dating this sibilant change, see D.J. Wiseman et al. Notes on some Problems in The Book of Daniel' TynB. (1965) 50-67.

${ }^{8}$ N.W. Porteous, Daniel, A Commentary: OTL (London, SCM 1965) .82. C. Boutflower, 'In and Around in the Book of Daniel' (London, SPCK 1923) $137 \mathrm{f}$.

${ }^{9}$ E.G.H. Kraeling, 'The Handwriting on the Wall' JBL 63 (1944) 11-8.
} 
eight-month rule of the boy king Labashi-Marduk (a Shekel) and Nabonidus with his co-regent Belshazzar (two Pereshin). This was later adapted for the shorter text 'Mina Shekel Peresh' by Ginsberg ${ }^{10}$ (Nebuchadnezzar, Evil-Merodach and Belshazzar) and Freedman ${ }^{11}$ (Nebuchadnezzar, Nabonidus and Belshazzar).

However, these ingenious theories lack support in the text, and although these scholars may regard their interpretations as self-evident, no exegetes have uncovered them till modern times. The evidence for 'Peresh' as 'half a Mina' is convincing, but not enough to exclude the possibility that it was used generally to mean a 'half' measure (from Aramaic PRS, or Akkadian parisu, 'to divide'), and that its precise meaning depends on the context. Its position in 'Mina Mina Shekel Peresh' suggests that in Daniel it means a half Shekel. This removes the problem of the order of the weights.

The problem remains that the Babylonian wise men did not appear to be able to read Aramaic. Aramaic was the lingua franca of the empire, so most of the people at the banquet would have been able to read the individual words. The interpretation of such words would be a small thing for men who were trained to find meaning in meaningless dreams and visions. They could have interpreted it as the monetary value of a sacrifice to be offered to Nabû, or the weight of gold which each soldier would capture in battle, or as Numbered (and) weighed are the Persians'. Given the size of the reward being offered, it seems incredible that no-one was willing to proffer a reasonable sounding guess.

However, the text suggests that they could not even read the words, let alone interpret them (Dn. 5:8). Zimmermann ${ }^{12}$ suggests that this means they could not 'vocalise' the words, though he does not say why they should have such difficulty with an official court language.

The rabbis and later Jewish commentators thought that perhaps it was written in unfamiliar characters, or in cypher, or

${ }^{10}$ H.L. Ginsberg, Studies in Daniel (New York, The Jewish Theological Seminary of America 1948) 24-6.

${ }^{11}$ D.N. Freedman, 'The Prayer of Nabonidus' BASOR 145 (1957) 31-2.

${ }^{12}$ Zimmerman op. cit., 206. 
vertically. ${ }^{13}$ Calvin simply said that God blinded the infidels, ${ }^{14}$ while Jeffrey ${ }^{15}$ dismissed the problem as a simple assumption by the story-teller that the Babylonians were not as clever as Daniel. Lacocque ${ }^{16}$ suggested that the words may have been Aramaic transliterated into cuneiform characters. The present paper makes a similar but simpler proposal: that the original writing was cuneiform numerals which Daniel translated into Aramaic.

There is one curious feature of the story which has not been explained by any of the theories concerning this writing. The text says that it was written using 'fingers' in the plural (Dn. 5:5), not 'a finger' as one would expect (cf. Ex. 31:18; Dt. 9:10). This phrase could imply that the hand scratched the wall with its fingers, and that these scratches were interpreted by Daniel as writing.

If a left hand were to scratch a surface with its fingers while it drew itself into a fist, it would leave a series of marks which could be interpreted in cuneiform as numbers. These numbers could be interpreted as 'Mina, Mina, Shekel and a half'. The marks would be three vertical strokes of the small finger, ring finger and middle finger, followed by a cross made by the vertical of the forefinger being bisected by the horizontal of the thumb - i.e. ' $|I|+$ '.

Cuneiform numerals are fairly straight-forward though sometimes ambiguous. ${ }^{17}$ A simple vertical stroke normally means 'one', though it can sometimes mean ' 60 ', which is usually discernable by context. ${ }^{18}$ A vertical crossed by a horizontal is a

\footnotetext{
${ }^{13}$ BSanh. 22a Montgomery op. cit., 264. S.R. Driver, Daniel (CBSC, CUP 1900) 69 .

${ }^{14} \mathrm{~J}$. Calvin, Commentary on the Book of Daniel (tr. T. Myers, Edinburgh, 1852) 322.

${ }^{15}$ A. Jeffery, 'Exegesis' Daniel, TIB VI, (Nashville, Abingdon Press 1956) 426.

${ }^{16}$ Lacocque op. cit., 97, a suggestion from private communication with Fr Pierre Grelot.

${ }^{17}$ For introductions to cuneiform numerals see: R. Caplice, Introduction to Akkadian (Biblical Institute, Rome, 1980) 122f. L.W. King, First Steps in Assyrian (London, Kegan Paul, Trench, Trübner \& Co Ltd., 1898), CXXXIIIf.

${ }^{18}$ L.A. Barton, The Origin and Development of Babylonian Writing 2 vols. (Baltimore, J.C. Heinrich 1913) I 147f argues that the marks for ' 1 ' and ' 60 ' may originally have been different. However by the time of Daniel they were both represented by a single down stroke (Barton I, 152). This did not normally cause confusion because the sexagesimal system was rarely used.
} 
half, and there are other symbols for 10, 100,600, and 1000 . Numbers are built up from left to right, highest to lowest denominations.

However, the interpretation of even a very simple cuneiform word or phrase is very difficult when separated from its context. The single vertical can mark the start of a male name, or the ideas of 'when' or 'to'. Barton, ${ }^{19}$ who tries sometimes to be a little too exhaustive, lists 185 possible meanings of the vertical crossed by a horizontal. Although these meanings were not all current in late-Babylonian texts, one can perhaps understand the consternation of the wise men of Babylon.

Daniel's stroke of genius or inspiration seems to have been to convert these marks into numbers and then into the names of the weights these numbers represent. The first three verticals could either be 'one' or 'sixty', so he reads the first two as ' 60 ', i.e. a Mina (60 shekels), and the third as a Shekel, making the last a Half. It would have been quite wrong of an accountant or priest to mix up the sexagesimal and the unitary values in this way, but for Daniel this opened up fresh possibilities for his interpretation. It did not matter for Daniel's present interpretation whether he had two Minas or two Shekels, so the number of these does not figure in his explanation (26-28). Later, however, as suggested below Daniel does explore other possibilities.

Having converted the meaningless marks into words, Daniel could then apply the normal techniques of wordplay. ${ }^{20}$ He revocalised the names of the weights as though they were Aramaic words and produced verbal participles. He did not have a written Aramaic source, so it did not matter that he changed the Aleph in $M N A$ to a He to make $M N H$, 'numbered'. Shekel, in the dental pronunciation common in Daniel, ${ }^{21}$ becomes $T Q L$, 'weighed'. The Peresh is pronounced Peres and becomes PRS, 'divided' or 'Persians'.

\footnotetext{
${ }^{19}$ Barton op. cit., II 45.

20M. Fishbane, 'The Qumran Pesher and Traits of Ancient Hermeneutics' in A. Shinan (ed.) Proceedings of the 6th World Congress of Jewish Studies I (Jerusalem, 1977) 97-114) 103f.

${ }^{21}$ Boutflower, op cit., 17.
} 
If this understanding of the writing on the wall is correct, Daniel interpreted ' $1 \mid 1+$ ' as ' $60,60,1,1 / 2$ ' - i.e. $121^{1 / 2}$. This understanding may also give an insight into the number system of the visionary chapters in Daniel. These are based largely on the number $3^{1 / 2}$, which is the numerical basis of the first vision (Dn. 7:25) and the last (Dn. 12:7). The number $3^{1 / 2}$ is also the simplest interpretation of these marks, each vertical is usually read as 'one', so these marks should be read as $1,1,1,1 / 2$ i.e. $3^{1 / 2}$. It may be postulated that the visions based on the number $3^{1 / 2}$ were meditations on this initial revelation.

This bold supposition finds some support when one looks at other numbers in Daniel. In chapter 9 the value $3^{1 / 2}$ occurs again, but as part of a much more complex series of numbers. The seventy years of Jeremiah 29:10 (Dn. 9:2) is interpreted as seventy 'weeks' of years, and divided into three groups of seven weeks, sixty-two weeks and one week (Dn. 9:25f). This last week is divided into two periods of $3^{1 / 2}$ years (Dn. 9:27). The reason for this division is not clear in the text, but one reason may be that the third possible numerical interpretation of ' $111 t^{\prime}$ ' is ' $60,1,1,1^{1 / 2}$ ', i.e. $62^{1 / 2}$. A period of sixty-two weeks is therefore placed immediately before the first half week. This not only leaves a period of seven weeks, but also provides a reason for dividing the last week into halves, thereby providing a link with chapter 7 .

This link between the vision of chapter 5 and the numerical prophesies in later chapters is clearly not contrived by a unifying editor or by a separate author of the later chapters. There is no mention of this link, and no hint that the numbers in the later chapters are related in any way to the writing on the wall. This therefore provides indirect evidence that both halves of the book of Daniel were written by the same person. This person would have to know about the cuneiform original of the writing on the wall, and would have to know how to re-interpret this cuneiform as other numerical values. These factors make it likely that the author was Daniel himself.

In conclusion, the original writing on the wall may have been the cuneiform marks ' $|1|+$ ', which could be the scratches made by the fingers of a left hand as it curled up into a fist. This could be read as $60,60,1,{ }^{1 / 2}$, or 'Mina, Mina, Shekel, Peresh' This supposition would explain why the other wise men could not 
read the writing and why the text says that it was written with 'fingers' and not 'a finger'.

This may also suggest an origin for most of the numerical values in the visionary chapters, which may be seen as meditations on other possible ways of computing these marks. At the feast, Daniel explored their value as $121^{1 / 2}$. The visionary chapters (7-12) explore the other two possible values of $3^{1 / 2}$ and $62^{1 / 2}$. This link between the narrative story of chapter 5 and the visionary chapters should be considered when discussing the composite nature of the book of Daniel. 